\title{
The Determinants of the Crop Residue Management in Pakistan: An Environmental Appraisal
}

\author{
Muhammad Rafiq1, Furqan Ahmad², Muhammad Atiq ${ }^{3}$
}

\begin{abstract}
This study highlights an important environmental problem of crop residue burning in open fields and investigates the main 'cost-push' factors of rice and wheat crop residue management in the district Gujranwala of Punjab, Pakistan. Burning of residue, is the second largest contributor to global warming after carbon dioxide, and it disturbs the key components of the agricultural ecosystem. Burning of residue is a quick way of clearing the field for the next crop. It also aids in controlling various pests, weeds, and diseases. The majority of the farmers are inclined to burn residue completely, followed by its complete removal in the study region because of the aforementioned benefits. This paper is based on a survey of 200 farmers interviewed from 28 villages of four Tehsils of the district Gujranwala, with a maximum number of 7 farmers from each village. A multinomial logit model technique is adopted to analyze the problem. Size of farm, length of straw, cattle ownership, avoiding late plantation of next crop and distance of the field from farmers' homes were found significantly affecting farmers' decision of following a particular residue management practice for rice crop. The use of wheat chopper machine, reading habits of agricultural publications and combine harvester were found main determinants for wheat residue management practices. Based on the results, we suggest a compensation mechanism to the farmers, similar to Payment for Ecosystem (PES) for the complete removal or incorporation of residue as it is an expensive solution. We also recommend an awareness-raising campaign regarding the use of wheat chopper machine and Kubota harvester to reduce open field burning of residue and the use of crop residue for bio-energy consumption.
\end{abstract}

Keywords: Environment, ecosystem, PES, multinomial logit model, Gujranwala

JEL: Q12; Q55

\section{Introduction}

The cultivation of rice and wheat crop generates two types of residue i.e. straw and husk. Straw is the height of rice or wheat stem from base to paddy, while husk

1 Assistant Professor, Institute of Management Sciences, Peshawar. Email: muhammad.rafiq@imsciences.edu.pk

2 Research Associate, Institute of Management Sciences, Peshawar.

3 Assistant Professor, Institute of Management Sciences, Peshawar.

\section{ARTICLE HISTORY}

31 Oct, 2018 Submission Received

22 Nov, 2018 First Review

09 May, 2019 Second Review

25 Nov, 2019 Third Review

05 Dec, 2019 Accepted 
is the residue resulting from net fruit of paddy. These are key components for the stability of agricultural ecosystems (Mobeen, 2009). To reduce the turnaround between successive crops, farmers follow various crop residue management practices, especially in places where rice and wheat cropping systems (RWCS) prevail. Crop residues are natural resources and are used by farmers for purposes such as feeding animals, composting, thatching (bhoosa) for rural homes, and fuel for domestic and industrial use. However, a large portion of the preceding crop residue is burnt in the field, primarily, to clear the field from straw and stubbles for the following crop. The issue of residue burning is severe in irrigated agricultural lands, particularly in mechanized RWCS (Derpsch \& Friedrich, 2010).

This study is an initiative to understand why farmers burn rice and wheat crops' residue; what alternative means can be adapted to dispose of the crops' residue, and when the farmers would be willing to reduce the open field burning of the crops' residue. Crop residues are generally considered useless, as unwanted rice and wheat residue is either burnt completely or only the lower part is burnt. Farmers follow various practices in order to manage the crops' residue efficiently. They also keep in mind the costs and benefits associated with following a particular residue management practice. The options available for farmers to manage the crops' residue are: to burn the residue left in the field after harvesting, to remove the residue from field, and to incorporate the residue in the soil. This paper highlights determinants for both the rice and wheat crops' residue management practices in the study region as there is just a single study done in Pakistan which elaborates the issue of 'rice residue' burning and its common management practices. However, that particular study does not highlight or analyze the residue management practices of wheat crop. Also, this paper opens ways to scientific studies to be conducted in places where the practice of residue burning is followed since crops' residue can be beneficially utilized for some other good purposes rather than wasting it by open field burning. Open field burning of crops' residue is the second largest contributor to environmental pollution and global warming. Therefore, there is a need for a study to draw attention to the issue of crops' residue management practices that which particular practice is followed by farmers and which particular practice ought to be followed.

The rest of the paper is organized as follows: in the ensuing section, we present the extant literature on crop residue burning and its effects, which is followed by an explication of the study design and rationale of sampling. Next, we describe the methodology and estimation strategy after which, results are presented and discussed. In the end, we conclude the paper and suggest policy recommendations. 


\section{Literature Review}

Crop residue burning has recently become an important sustainability problem because of its harmful ecological effects and negative effects on the human health. The problem is highlighted, especially, in winters, when the smoke arising from the crop residue burning mixes with the natural fog and becomes 'smog'. Nevertheless, burning of crop residues also results in hazardous human health impacts as it results in increased particles in the air, which is associated with an increase in illness and death, particularly in people with heart and lung conditions. Besides, the release of soot particles and smoke causes human health problems (Pathak, Bhatia, Jain \& Aggarwal, 2010), and emission of greenhouse gases such as nitrous oxide, carbon dioxide, methane cause global warming (Cavalett, Slettmo \& Cherubini, 2018). Crop residue burning during wheat and rice harvesting periods, is a significant source of air polloution in the Indo-Genetic plains (Pathak et al., 2010). The burning of crops' residues adversely affects regional climate, production yields, and the human health (Jain, Bhatia \& Pathak, 2014; Cavalett et al., 2018). The burning of fossil fuels and biomass emit carbon monoxide which is one of the causes for climate change (Auffhammer, Ramanathan \& Vincent, 2012). The authors found the positive impact of reduction in climate change and greenhouse gases on rice production. They estimated that rice yield and the area harvested would have increased by 5.7 percent during 1966-2002 if increased droughts, warmer nights and lower rainfall had not occurred. If Indian farmers had not burned crop residue, they would have been much prosperous now.

Scholars report conflicting results regarding various residue management practices and their impact on the yields of next crop. Some scholars have found that burning of residue improves the soil nutrients and has positive impact on the yield of next crop (Preez, Steyn \& Kotze, 2001). Whereas, other studies report incorporation of residue in the field as the best choice for greater yields of next crop (Bahrani, Raufat \& Ghadiri, 2007; Singh \& Kumar, 2018). Bahrani et al. (2007) suggest that maximum crop yield can be obtained if $25-50 \%$ of wheat residues are incorporated in soil as compared to other treatments for increasing crop yield. Another potential solution to crop residue management is the conversion of crop residues into energy, as for example, in India, rice straw is converted into biogas by utilizing bio-methanation technology (Bhuvaneshwari, Hettiarachchi \& Meegoda, 2019). Crop residue burning results in loss of plant nutrients such as Nitrogen, Phosphorous, Potassium and Sulphur (Gupta et al., 2004), hence, adversely affecting the physical properties of soil.

The issue of rice crop residue burning has been addressed in the study of Ahmad and Ahmad (2013). The authors report the factors because of which farmers are forced to burn rice residue in the Punjab province, Pakistan. They find that those farmers who are own operator, have small farm holding and have cattle on field favor to remove the 
rice residue to fulfill their needs. In contrast, farmers who have large size of farms and perceive residue left in the field as a major hurdle in the use of farm machinery, burn either complete residue or only its lower parts. The study suggested that farmers be compensated with about Rs. 3600/acre (cost of removal or incorporation of residue) if burning of rice residueis to be avoided. Bhuvaneshwari et al. (2019) suggest that institutional mechanisms such as governmental and comunity support need to be in place for solving the issue of crop residue burning. Such institutional mechanisms coupled with stakeholders' education can aid in adopting other means of removal of crop residue and in finding the alternative uses of such residue.

\section{Survey Design and Rationale for Sampling}

\subsection{Study area}

The district Gujranwala of the Punjab Province is selected for this study because of its importance in terms of rice-wheat acreage. Also, the area allocated to the RWCS pattern is highest in the district compared to other districts of the Province. RWCS is amongst the most widespread cropping systems in Pakistan, covering 2.1 million hectares area, of which nearly three-fifths of the area falls in the Punjab province (GoP, 2003). The total geographical area of the district is 906.352 (000 acres) of which the cultivable area is 778.210 (000 acres) with cropping intensity of 191.54 percent and with major crop rotation of rice-wheat and wheat-rice (Land Revenue Department, Gujranwala). The Rice and wheat cropping system of the Punjab mainly covers Gujranwala, Sheikhupura, and Sialkot Districts with some parts of Gujrat and Lahore Districts as well. Percentage area allocated to wheat, rice and berseem in these districts of the Punjab province is: Gujranwala 87\%, 13\%, 89\%; Sheikhupura 71\%, 20\%, 94\%; Hafizabad 74\%, 9\% and 77\% for wheat, rice and berseem, respectively (Hussain et al. 2012).

Wheat is the major crop during the Rabi season (November to April) and rice is the major crop during Kharif season (May to October). Total cropped area and area under rice and wheat is the highest in Gujranwala district followed by district Sialkot among various districts following RWCS (Ahmad \& Ahmad, 2013). The major soil types are coarse loamy soils, coarse loamy and fine loamy associations (Soil and water testing lab, Gujranwala). There are four Tehsils, 802 villages and 19 Union Councils in the district and almost all cultivable area of the district is irrigated (Agriculture Department, Gujranwala). Farmers either have access to the canal irrigation system or have own tube-wells, both electric and diesel. The district also receives $562 \mathrm{~mm}$ rainfall annually (on average 47 normal rainy days/annum).

\subsection{Crop residue management and associated fators in study area}


Farmers in the study area follow various practices in order to manage the crops' residue efficiently. They also keep in mind the costs and benefits associated with following a particular residue management practice. The options available to them to manage the crops' residue are: to burn the residue left in the field after harvesting, to remove the residue from the field, and to incorporate the residue in the soil. Complete incorporation of rice and wheat crops' residue was not found on any plot during field visits of the study area. The barriers for incorporation of residue were: the unavailability of appropriate farm machinery or its expensive usage, and the negative impact of residue incorporation on the following crop. The decision to follow a certain residue management practice is influenced by various factors which are explained in the following sub-sections.

\subsubsection{Size of farm (in acre)}

The farm size is the most important variable in determining a particular residue management decision as evidenced in the extant studies done in India, Bangladesh, and Pakistan. Farmers holding large farms are less interested in the collection and removal of straw because they use fodder as feed for animals. Therefore, removal of the straw is useless for them and they go for the burning of residue. The size of the farm includes both farmers' owned and rented lands in acres. Small landholders might use the residue as animal feed and for domestic energy purposes. The variable is expected to be positively related to the burning of residue. As size of farm holding increases, few farmers may be interested in the collection of necessary residue and most will burn the residue to clear the field from straw and stubbles and prepare it for next crop. This is a continuous variable and present study examined residue management decisions among farmers of four categories i.e. farmers holding land between 1-5 acres, farmers holding land between 6-10 acres, farmers holding land between 11-15 acres and farmers holding land $16+$ acres during time period of field visit.

\subsubsection{Length of straw (in feet)}

Different varieties of rice and wheat crops have different straw sizes and more straw is left in the field after harvesting with combine harvester if the length is larger. Managing longer straw is a big challenge for farmers. Typically, rice and wheat straw is used for animals' feeding but in most plots, the residue is burnt because of its length. The removal of larger straw is very expensive and time-consuming, and the least expensive choice for farmers is to burn the straw. The straw length and residue burning is assumed to be positively related because mostly coarse varieties of rice and wheat crop have larger straws, which are not liked by animals as feed. Therefore, the larger the length of straw, the more the farmer is inclined to burn the residue. The variable is continuous and this factor affects both rice and wheat residue management 
decision, therefore, is used in both cases.

\subsubsection{Distance of field from farmer's residence (in $\mathrm{km}$ )}

Distance between farmers' homes and the field matters a lot in making certain residue management decisions. If the distance between the two is more, the removal of residue will associate collection of residue costs, loading and unloading costs, and transportation costs, hence, making it irrational choice. Therefore, it is assumed that farmers living far from their fields are more curious to burn the residue on the field rather than removing it. This variable is certainly important for both rice and wheat crop residues. To examine whether a particular residue management decision is affected by distance between farmers' home and field, different categories, such as 0-1 km distance, $1-2 \mathrm{~km}$ distance and 2+ distances between the two are used.

\subsubsection{Combine harvester}

The use of combine harvester for harvesting rice and wheat crops leaves one to two feet residue un-harvested in the field. This creates problems for the use of farm machinery to prepare the field for the next crop. The dummies generated are; ' 1 ' if rice or wheat crop is harvested by combine harvester and farmers view it as a factor for residue burning and ' 0 ' otherwise.

\subsubsection{Reading agricultural publications}

The Agricultural Department of Punjab publishes agricultural magazines on a weekly and monthly basis, which contain useful information for farmers regarding suitable time for cultivation of various crops, nutrients required for different crops from time to time, etc. It is expected that those who read agricultural magazines are more inclined to remove residue from the field and the burning of residue practice is not favored by that group. The dummies generated for the variable are ' 1 ' if the farmer reads agricultural magazines and the burning of residue practice is not favored by him and ' 0 ' otherwise.

Interestingly, during data collection, it came to our knowledge that farmers' experience does not play any significant role in farmers' decision to following any particular residue management practice. They were more concerned with the benefits associated with that particular residue management practice as can be noticed from the results section. Most of the farmers burnt the residue in the open field as they thought the burning of residue had a positive impact on the yields of the next crop. Such views are also supported by a few research studies. Therefore, to a majority of the farmers, farming experience has nothing to do with following any particular residue management practice. That is why farmers' experience is not used as an explanatory 
variable in this paper.

\subsubsection{To avoid late plantation of the following crop}

The duration between harvesting rice crop and initiating preparations to cultivate the wheat crop plays an important role. Farmers' behavior regarding residue management depends mostly on turnaround between the successive cultivations. If a particular farmer wants to reduce the turnaround between successive crops, the best choice available for him is to burn the residue and clear the field from straw and stubbles. This variable is used only for rice residue management study as the time gap between rice harvesting and wheat sowing is short (less than 20 days). Farmers have enough time between wheat harvesting and rice cultivation, therefore, the variable is not used in wheat residue management study. The variable is categorical and is used as a dummy variable in the study. The values assigned are ' 1 ' if farmer's intention of burning residue is to avoid late plantation of the next crop and ' 0 ' otherwise.

\subsubsection{Occupation}

If the farmers' primary occupation is farming, they can closely examine the impacts of various residue management practices on the yields of the following crops. Therefore, those farmers whose primary occupation is farming will be aware of the negative or positive impacts of burning residue on the crops after successive cultivation. It is expected that farmers having farming as primary occupation would not burn residue and more likely would go for the removal of crops' residue. The variable is categorical and is used for rice residue study only. Dummies generated for are ' 1 ' if farmers' primary occupation is farming and ' $O$ ' otherwise.

\subsubsection{Cattle ownership}

Crop residue is removed for three purposes i.e. as animal feed, for selling purpose and for meeting domestic energy requirements. The rice and wheat residue is not utilized for any other purpose in Pakistan. Farmers having more cattle and small farm size are eager to remove residue than those having less number of cattle at home. The variable is expected to be negatively correlated with farm size, i.e. as farm size increases, removal of residue from three to four acres will be enough to feed the animals and the remaining residue will be burnt. The relationship is expected to be negative between cattle ownership and burning/partial incorporation of residue in the field and is positively related to the removal of residue. This is also a continuous variable and is used only in rice residue management practices, as use of wheat residue for animals feed is rare (as seen in the study region during field visit) and wheat residue is removed mainly for selling purpose. 


\subsubsection{Positive impact of residue burning on the following crop}

Burning of crops' residue has a short term positive impact on the following crop as thought by farmers and confirmed by some literature. Most of the farmers think that burnt residue improves soil fertility, which results in increased yield of the following crop. This variable was introduced during field study as seen affecting the rice residue management decision. However, other farmers were of the view that there is no impact or negative impact of burning residue on the following crop. The variable is categorical and dummies are generated as ' 1 ' if the intention of rice crop burning is its positive impact on the next crop and ' 0 ' otherwise.

\subsubsection{Wheat chopper machine}

This variable was introduced during field surveys and affects wheat residue management decisions. Wheat chopper machine harvests the wheat crop from the bottom and stores the residue in the back cage, which is then either used for feeding cattle or is sold in the market. The variable is used as categorical and dummies generated are; ' 1 ' if residue is removed from plots where crop is harvested with wheat chopper and ' 0 ' otherwise.

\subsubsection{Negative impact of wheat residue incorporation on next crop}

This variable was also included in the study after during field surveys. Unlike rice residue partial incorporation which was thought beneficial for soil nutrients by most farmers, the incorporation/partial incorporation of wheat residue was thought to be adversely affecting the next crop by farmers. They were of the view that wheat residue does not mix in the soil, hence, preventing the seeds of following crop to spillover. Therefore, wheat residue is either completely or partially burnt in the field to avoid its negative impacts. The variable is categorical and dummies used for this variable are ' 1 ' if wheat residue is burnt by farmers due to this reason and ' 0 ' otherwise.

\subsubsection{Convenience in the use of farm machinery}

Most farmers burn wheat residue because of its mixing problem in the soil and hurdle in the use of farm equipment. When the residue is burnt in the field, the use of farm machinery and preparation of the field for the next crop becomes easier for the farmer. This variable is also categorical and categories assigned for the variable are ' 1 ' if the farmers' perception of burning wheat residue is because of its convenience in the use of farm equipment and ' $O$ ' otherwise.

\subsubsection{Contact with the extension agent}

The extension agents (who are representative of the agricultural department) 
have the responsibility to visit farmers and provide information that better suits the circumstances. The variable is included in the study because farmers who have contact with the extension agent might be better aware of benefits while following a particular residue management practice. The variable is expected to be positively related to removal or incorporation of residue as extension agents do not favor residue burning practice because of its negative impacts on crops' production and environment. This is a dummy and categories assigned to this are ' 1 ' if Famer is in contact with the extension agent and avoids burning of residue and ' 0 ' otherwise. During the field study, variables such as farmer's age and experience, farmer' education level, farmer' caste, soil type, etc., were not found noticeably affecting particular residue management decisions and hence, were not included in the study.

\subsection{Sampling}

A multistage sampling technique was adopted for the collection of data. At the outset, we had selected district Gujranwala of Punjab because of its importance in terms of rice-wheat acreage. The district has four Tehsils namely; Gujranwala city, Kamonke, Wazirabad and Nowshera Virkan. The sample for this study included farmers of twenty-eight villages of the district, where seven villages from each Tehsil were randomly selected. The tehsil-wise fragment of the villages in which the data was collected is given in table 1 below.

Table 1: Tehsil-Wise Fragment of the Villages

\begin{tabular}{|c|c|c|c|c|}
\hline Tehsil & $\begin{array}{c}\text { Total number of } \\
\text { villages }\end{array}$ & $\begin{array}{c}\text { Surveyed villages } \\
\text { from each Tehsil }\end{array}$ & $\begin{array}{c}\text { Percentage } \\
\text { w.r.t. Tehsil wise } \\
\text { villages }\end{array}$ & $\begin{array}{c}\text { Percentage w.r.t. } \\
\text { sampled villages }\end{array}$ \\
\hline Gujranwala & 205 & 7 & 3.4 & 25 \\
\hline Kamonke & 169 & 7 & 4.2 & 25 \\
\hline Wazirabad & 243 & 7 & 2.9 & 25 \\
\hline Nowshera Virkan & 185 & 7 & 3.8 & 25 \\
\hline Total & 802 & 28 & 3.491 & 100 \\
\hline
\end{tabular}

The villages from each Tehsil were selected from the list provided by the Agriculture Extension Department of Gujranwala district. A well-structured questionnaire was used for the collection of data after a pre-test of the instrument. The criteria for selecting a village was based on throwing a dice. The first six villages were then eliminated from the list to overcome the error of repetition. 7 farmers were selected randomly from each village to collect the desired information. The total sample size for the study is 200 respondents. The data was collected with the help of a local guide. 
The collaboration and support of the Agriculture Department Gujranwala proved extremely useful in the timely completion of the survey. The data for the study was collected in the months of November and December 2013.

\section{Methodology and Estimation Strategy}

The conventional approach treats certain technology adoption as a binary decision which depends on profitability, relative advantage at alternative technology and farm and farmers' characteristics (Lee \& Stewart, 1983; Qaim \& Zilberman, 2003; Useche, Barham \& Foltz, 2009). These studies estimate the factors of adopting certain technology by estimating the binary dependent variable in terms of predictor variables. In this study, farmers are following more than two residue management practices, hence, the traditional binary approach would not be an appropriate choice for estimation. Rice and Wheat crops' residue management decision can be modeled as a multi-valued categorical variable in which farmers choose among various management practices like complete removal of residue, complete burning of residue, partial burning of residue, partial incorporation and full incorporation of residue. However, the full incorporation of rice or wheat residue was not found in the surveyed region and consequently, not taken into account.

Therefore, multinomial logit model has been used for the estimation of nominal choices to various determinants of rice and wheat crops' residue management practices because the response variable is multi-valued and categorical. The simplest approach to multinomial data is to recommend one of the response categories as a base outcome or reference category and then to calculate log-odds for all other categories relative to the base-outcome, and finally, let the log-odds be a linear function of the explanatory variables. The partial incorporation of residue is chosen as base category for this study and the other residue management practices are discussed relative to the base category. The researcher is asked to choose one category of the categorical dependent variable as the base category when using multinomial logit model in "STATA". By default, the software uses the most frequent category in the multi-valued categorical dependent variable as base-outcome. Therefore, the partial incorporation of residue was manually chosen as base-outcome.

\subsection{Modeling multinomial logit}

A set of $\beta_{\mathrm{j}}$ (vector of regressors' coefficients) for the $J^{\text {th }}$ (residue management practices) category is modeled as:

$\log \left(\mathrm{p}_{\mathrm{ij}} / \mathrm{p}_{\mathrm{iI}}\right)=\beta_{0 \mathrm{j}}+\beta_{1 \mathrm{j}} \mathrm{X}_{\mathrm{i}}$

Where $i$ is the $i^{\text {th }}$ farmer and $j$ is the $\mathrm{J}^{\text {th }}$ alternative choice to each farmer. 'I' is that 
particular residue management practice which has been chosen by the $i^{\text {th }}$ farmer. $\mathrm{X}_{\mathrm{i}}$ shows the vector of explanatory variables affecting residue management decisions. The model fitted is not quite right because the error distribution of the polytomous dependent variable is not correctly specified. This can be done effectively by specifying a multinomial logit model. The log-odds of each predictor are then associated with the response categories relative to some baseline category. As a linear function of covariates is:

$$
\log \left(\mathrm{p}_{\mathrm{ij}} / \mathrm{p}_{\mathrm{iI}}\right)=\beta_{0 \mathrm{j}}+\beta_{1 \mathrm{j}} \mathrm{X}_{\mathrm{i} 1}+\beta_{2 \mathrm{j}} \mathrm{X}_{\mathrm{i} 2}+\ldots+\beta_{\mathrm{pj}} \mathrm{X}_{\mathrm{ip}}
$$

Where $i$ is the $i^{\text {th }}$ farmer and $\mathrm{J}$ is the $\mathrm{J}^{\text {th }}$ category of the dependent variable; 'I' is that particular residue management practice which has been chosen by the $i^{\text {th }}$ farmer. $X_{i}$ shows the vector of explanatory variables affecting residue management decisions. It is compulsory to recommend one of the dependent variable categories as the base-outcome. The Multinomial logit model assumes that the log-odds of each response category follow a linear model;

$$
\eta_{i j}=\log \frac{\pi i j}{\pi i j}=a i+X i \beta i
$$

Where $\alpha_{j}$ is the constant intercept and $\beta_{j}$ is a vector of repressors' coefficients for $j_{s}$ categories and estimates J-1 models. The constant is written explicitly because it assumes the model's matrix $\mathbf{X}$ does not include a column of ones. Multinomial logit model does not make the assumptions of normality, linearity, and homogeneity of variance for the predictor variables (Hoffman \& Duncan, 1998). Because it does not impose these requirements, it is preferred to discriminate analysis when the data does not satisfy these assumptions.

Suppose a respondent $i$ chooses among $m$ alternatives in a choice set. Let $\pi_{\mathrm{jk}}$ denote the probability that the respondent $i$ chooses alternative $\mathrm{k}$, let $\chi_{j}$ represent the characteristics of the respondent $i$. Since the generalized logit model focuses on the individual as the unit of analysis and uses individual characteristics as explanatory variables. The explanatory variables, being characteristics of an individual, are constant over the alternatives. The probability that respondent $i$ choose an alternative $\mathrm{k}$ is;

$$
\Pi_{i k}=\frac{\exp (\beta k X i)}{\sum_{i=1}^{m} \exp (\beta i X i)}
$$

Dividing by numerator, the model becomes;

$$
\Pi_{i k}=\frac{1}{\left.\sum_{i=1}^{m} \exp [(\beta i-\beta k) X i)\right]}
$$

Where $\prod_{i k}$ is benefits associated with $\mathrm{k}^{\text {th }}$ alternative and hence selected by $i^{\text {th }}$ farmer. $\beta_{1, \ldots . . .} \beta_{\mathrm{m}}$ are $m$ vectors of unknown regression parameters (each of which is different, even though $X_{\mathrm{j}}$ is constant across alternatives). Since, $\sum_{i=1}^{m} \square \pi_{i k}=1$ the $m$ sets 
of parameters are not unique. By setting the desired set of coefficients the null i.e. $\beta_{\mathrm{m}}=0$ (as in our case the partial incorporation of residue as reference category), the coefficients $\beta_{\mathrm{k}}$ represent the effects of the $\mathrm{X}$ variables on the probability of choosing the $\mathrm{K}^{\text {th }}$ alternative over the last alternative. In fitting such a model, you estimate $m-1$ sets of regression coefficients.

The above-mentioned model has been used for the estimation purpose in this study. The same model is used separately for estimating determinants of both rice and wheat residue management practices. Since this study examines the residue management practices in terms of partial incorporation,therefore, partial incorporation is used as a reference category. The values assigned for the response categories are; ' 0 ' for partial incorporation of residue, ' 1 ' for complete removal of residue, '2' for partial burning and ' 3 ' for complete burning of rice residue. The log-odds of predictors are calculated for all the response categories in terms of reference category as there are three replicates of the predictors' i.e. (a) partial incorporation relative to complete removal, (b) partial incorporation relative to partial burning, and (c) partial incorporation relative to complete burning of rice or wheat residue.

\section{Results and Discussion}

Results and discussion including descriptive statistics and econometric estimation results are delineated in the following sections.

\subsection{Descriptive Statistics}

More than half of the farmers of the study area are illiterate $(54.5 \%)$. This is followed by farmers having education of 6-10 years of education. Farmers belonging to Tehsil and District Gujranwala were found having some year of education as compare to other Tehsils of the District. Regarding age, farmers of age between 41-60, dominate the sample size, followed by the age group of $21-40$ years. Additionally, about 46.5 percent of the farmers have $16+$ acres of farm holding (including own and rented in farms) while 22.5 percent of the farmers own land of 6-10 acres (see table 2).

Table 2: Descriptive and Demographic Statistics of the Respondents

\begin{tabular}{|c|c|c|c|}
\hline Criteria & Category & Frequency & Percent \% \\
\hline \multirow{2}{*}{$\begin{array}{c}\text { Respondents Age Dis- } \\
\text { tribution (in Years) }\end{array}$} & $21-40$ & 85 & 42.50 \\
\cline { 2 - 4 } & $41-60$ & 87 & 43.50 \\
\cline { 2 - 4 } & $60+$ & 28 & 14.00 \\
\cline { 2 - 4 } & Total & 200 & $100 \%$ \\
\hline
\end{tabular}




\begin{tabular}{|c|c|c|c|}
\hline \multirow{5}{*}{$\begin{array}{c}\text { Respondent's } \\
\text { Education (Years of } \\
\text { Schooling) }\end{array}$} & 0 & 109 & 54.50 \\
\hline & $1-5$ & 27 & 13.50 \\
\hline & $6-10$ & 48 & 24 \\
\hline & $10+$ & 16 & 8 \\
\hline & Total & 200 & $100 \%$ \\
\hline \multirow[t]{5}{*}{ No. of cattle on field } & $0-4$ & 85 & 42.50 \\
\hline & $5-8$ & 83 & 41.50 \\
\hline & $9-12$ & 21 & 10.50 \\
\hline & $12+$ & 11 & 5.50 \\
\hline & Total & 200 & $100 \%$ \\
\hline \multirow{5}{*}{$\begin{array}{c}\text { Farm Size Owned } \\
\text { in the Year } 2013 \\
\text { (including own land } \\
\text { plus rented-in land) in } \\
\text { Acres }\end{array}$} & $1.5-5$ & 36 & 18 \\
\hline & $6-10$ & 45 & 22.50 \\
\hline & $11-15$ & 26 & 13 \\
\hline & $16^{+}$ & 93 & 46.50 \\
\hline & Total & 200 & $100 \%$ \\
\hline \multirow{3}{*}{$\begin{array}{l}\text { Farmers' Contact with } \\
\text { the Extention Member }\end{array}$} & Means of Contact & Frequency & Percent \\
\hline & $\begin{array}{l}\text { Through visits (from } \\
\text { either side) }\end{array}$ & 50 & $25 \%$ \\
\hline & $\begin{array}{l}\text { Contact through } \\
\text { Extention Helpline }\end{array}$ & 20 & $10 \%$ \\
\hline \multirow{2}{*}{$\begin{array}{l}\text { Reading of Agricultur- } \\
\text { al Publications by the } \\
\text { farmers }\end{array}$} & Frequency & Percent & \\
\hline & 46 & $23 \%$ & \\
\hline \multirow{3}{*}{$\begin{array}{c}\text { Means of Harvesting } \\
\text { of Rice Crop }\end{array}$} & Farm Machinery & Rented in Frequency & Percentage \\
\hline & Combine & 118 & 59 \\
\hline & Kubota Harvester & 56 & 28 \\
\hline \multirow{5}{*}{$\begin{array}{c}\text { Means of Harvesting } \\
\text { of Wheat Crop }\end{array}$} & Farm Machinery used & Rented in Frequency & Percentage \\
\hline & Combine & 98 & 49 \\
\hline & $\begin{array}{c}\text { Wheat Chopper } \\
\text { Machine }\end{array}$ & 80 & 40 \\
\hline & Manually Harvested & 22 & 11 \\
\hline & Total & 200 & $100 \%$ \\
\hline
\end{tabular}

More than half of the farmers harvest the rice crop using combine harvester (59 percent) followed by those using Kubota harvester (28 percent). Only 13 percent of them manually harvest the rice crop. Interestingly, some farmers were using both 
combine and Kubota harvester. It was found that Kubota harvester is used only on some of the plots for which they remove residue with their animals, while on other plots, crop is harvested using combine harvester, and the residue is burnt.

Majority of the wheat crop is also harvested by using combine harvester followed by wheat chopper machine. Table 3 shows the area allocation to rice and wheat crops in each Tehsil of District Gujranwala along with different crop residue management practices. The dominant area for rice crop is allocated to Super-Basmati followed by Basmati-386 and other varieties which include irri, basmati-515, basmati-385, super fan, Basmati Pak, etc. Area allocated to wheat crop, vegetables and Kharif and Rabi fodder can also be seen from Table 3 below.

Table 3: Area under Rice and Wheat Crop

\begin{tabular}{|c|c|c|c|c|c|c|}
\hline \multirow{2}{*}{$\begin{array}{l}\text { Variety of } \\
\text { Rice Crop }\end{array}$} & \multirow{2}{*}{$\begin{array}{l}\text { Area (in } \\
\text { acre) }\end{array}$} & \multicolumn{5}{|c|}{ Residue Management Practices in \% } \\
\hline & & $\begin{array}{l}\text { Complete } \\
\text { Removal }\end{array}$ & $\begin{array}{l}\text { Complete } \\
\text { Burning }\end{array}$ & $\begin{array}{l}\text { Upper part } \\
\text { Removal } \\
\text { and lower } \\
\text { Part Burn- } \\
\text { ing }\end{array}$ & $\begin{array}{c}\text { Upper Part } \\
\text { Removal } \\
\text { and lower } \\
\text { Part Incor- } \\
\text { poration }\end{array}$ & $\begin{array}{l}\text { Complete } \\
\text { Incorpora- } \\
\text { tion }\end{array}$ \\
\hline $\begin{array}{c}\text { Super } \\
\text { Basmati }\end{array}$ & 2756 & 34.00 & 26.50 & 25.00 & 14.50 & 00 \\
\hline Basmati-386 & 1623 & 42.00 & 28.00 & 15.50 & 14.50 & 00 \\
\hline $\begin{array}{c}\text { Other } \\
\text { varieties }\end{array}$ & 174.5 & 24.50 & 46.50 & 18.00 & 11.00 & 00 \\
\hline $\begin{array}{l}\text { Kharif } \\
\text { Fodder }\end{array}$ & 441 & - & $m$ & $m$ & $m$ & $-m$ \\
\hline $\begin{array}{l}\text { Summer } \\
\text { Vegetables }\end{array}$ & 85 & 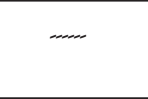 & $\ldots$ & $-m$ & $\ldots$ & - \\
\hline Total & 5079.5 & 33.50 & 34.00 & 19.50 & 13.00 & $100 \%$ \\
\hline $\begin{array}{l}\text { Wheat } \\
\text { Crop }\end{array}$ & 4313 & 26.50 & 26.50 & 30.50 & 16.50 & 00 \\
\hline $\begin{array}{l}\text { Rabi Fod- } \\
\text { der }\end{array}$ & 633 & m. & $\ldots$ & $-m$ & $\ldots$ & $\ldots$ \\
\hline $\begin{array}{c}\text { Winter } \\
\text { Vegetables }\end{array}$ & 133.5 & - & $\ldots$ & $\ldots$ & 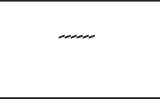 & $\ldots$ \\
\hline Total & 5079.5 & 26.50 & 26.50 & 30.50 & 16.50 & $100 \%$ \\
\hline
\end{tabular}

\subsection{Results of multinomial logit model}

The results of the Multinomial Logit model of various residue management 
practices are presented in Table 4 and Table 5 for Rice and wheat, respectively.

\subsubsection{Results and discussion of rice residue management practices}

Table 4 shows the results of the multinomial logit model (log-odds) for the rice residue. The negative coefficient of "to avoid late plantation of the following crop" for complete removal of the rice residue indicates that farmers do not get enough time to remove the rice residue and then to prepare the field for the following wheat crop. They hardly get 15-20 days to harvest rice crop and then arrange the field for the cultivation of wheat crop. Only those farmers who used to produce Basmati-386, Super-fan and other rice varieties get time interval between rice and wheat crop season because these varieties of rice mature early (within 60-75 days) than Super-Basmati rice. Most of the farmers of the study area produce Super-Basmati and Basmati-386 variety of rice. Therefore, the probability of burning rice residue for those producing Super-Basmati is high as compared to those who produce other varieties that mature early than super-basmati. The Log-odds of multinomial logit of "XR" for complete removal of residue are -6.050133 and are statistically significant. The log-odds for complete burning ad upper part removal and lower part burning of rice residue are 4.852389 and 4.102321 respectively and are significant. The variable is consistent with economic theory.

Table 4: Results of Multinomial Logit Model (log odds) of Rice Crop

\begin{tabular}{|c|c|c|c|c|}
\hline Symbol & Variable Name & $\begin{array}{c}\text { Complete } \\
\text { Removal of Rice } \\
\text { Residue }\end{array}$ & $\begin{array}{c}\text { Complete } \\
\text { Burning of Rice } \\
\text { Residue } \\
\end{array}$ & $\begin{array}{l}\text { Upper Part re- } \\
\text { moval and lower } \\
\text { Part Burning }\end{array}$ \\
\hline XR1 & $\begin{array}{c}\text { To Avoid late plantation } \\
\text { of wheat crop }\end{array}$ & $\begin{array}{l}-6.050133^{*} \\
(3.360163) \\
\end{array}$ & $\begin{array}{l}4.852389^{* *} \\
(2.246629)\end{array}$ & $\begin{array}{l}4.102321^{*} \\
(2.191115)\end{array}$ \\
\hline $\mathrm{XR} 2$ & Farm Size in Acres & $\begin{array}{c}-0.4652518^{* *} \\
(0.2185598)\end{array}$ & $\begin{array}{c}0.4396107 * * * \\
(0.1606088)\end{array}$ & $\begin{array}{c}0.3484258^{* *} \\
(0.1592834)\end{array}$ \\
\hline XR3 & Straw length in Feet & $\begin{array}{l}-7.327439^{*} \\
(3.863443)\end{array}$ & $\begin{array}{l}8.523872^{* *} \\
(4.196723)\end{array}$ & $\begin{array}{c}6.99977^{*} \\
(4.126849)\end{array}$ \\
\hline XR4 & No. of Cattle on Field & $\begin{array}{l}0.8758508^{*} \\
(0.4885261)\end{array}$ & $\begin{array}{l}-1.185579^{* *} \\
(0.5322587)\end{array}$ & $\begin{array}{l}-1.145018^{* *} \\
(0.5191118)\end{array}$ \\
\hline XR5 & $\begin{array}{l}\text { Distance of Farm to } \\
\text { Farmer's Residence place } \\
\text { (in Km) }\end{array}$ & $\begin{array}{c}-5.446158^{* *} \\
(2.257487)\end{array}$ & $\begin{array}{l}3.382366^{*} \\
(2.087162)\end{array}$ & $\begin{array}{l}3.520179^{*} \\
(2.080611)\end{array}$ \\
\hline XR6 & $\begin{array}{l}\text { Positive Impact on the } \\
\text { Next Crop }\end{array}$ & $\begin{array}{l}-4.432786 \\
(4.167091) \\
\end{array}$ & $\begin{array}{c}7.413933^{* *} \\
(3.6033) \\
\end{array}$ & $\begin{array}{l}6.437715^{*} \\
(3.572451) \\
\end{array}$ \\
\hline XR7 & Combine Harvester & $\begin{array}{l}0.8675119 \\
(2.092356)\end{array}$ & $\begin{array}{l}-0.6271765 \\
(1.909865)\end{array}$ & $\begin{array}{c}0.7139334 \\
(1.85445)\end{array}$ \\
\hline
\end{tabular}




\begin{tabular}{|c|c|c|c|c|}
\hline XR8 & $\begin{array}{c}\text { Reading Agricultural } \\
\text { Publications }\end{array}$ & $\begin{array}{c}2.951648 \\
(13.22817)\end{array}$ & $\begin{array}{c}-2.314703 \\
(1.721514)\end{array}$ & $\begin{array}{c}-1.738258 \\
(1.661325)\end{array}$ \\
\hline \multirow{2}{*}{ XR9 } & Occupation & $\begin{array}{c}1.22579 \\
(3.717174)\end{array}$ & $\begin{array}{l}-2.166605 \\
(1.965173)\end{array}$ & $\begin{array}{l}-1.764853 \\
(1.897535)\end{array}$ \\
\hline \multirow{2}{*}{ Cons } & Constant & $31.64979^{*}$ & $-46.13128^{* *}$ & $-37.71874^{*}$ \\
& & $(16.77626)$ & $(22.97611)$ & $(22.63314)$ \\
\hline
\end{tabular}

Standard error in parentheses, ${ }^{* * *} \mathrm{p}<0.01,{ }^{* *} \mathrm{p}<0.05,{ }^{*} \mathrm{p}<0.10$

Note: - Here the base outcome of the multi-valued categorical dependent variable is "upper part removal and lower part incorporation (Partial Incorporation)" practices, therefore, results of that categorical variable are not mentioned.

Farm size is the most important variable and plays a significant role in the rice residue management practices. $\mathrm{XR}_{2}$ is the size of farm holding by the farmer at $t-1$ time period and was expected as positively related to the burning of rice residue. Significant negative coefficient of the "farm size" for complete removal of residue and highly significant positive coefficient of "farm size" for complete burning and partial burning of rice residue confirm the proposition that farmers having smaller farms are more inclined to remove the rice residue and those having larger farms are more inclined towards burning either completely or only the lower parts of the rice residue.

Some varieties of rice have a very long straw which includes basmati-515, super-fan, and basmati-386. Length of straw is also a very important variable which affects rice residue management decision. Harvesting the rice crop with combine harvester leaves about 2 feet of straw (called mud) in the field, which becomes serious problem for the use of farm machinery in order to prepare the field for the coming wheat crop. The incorporation of residue is also a big challenge if the straw length is large. The log-odds of multinomial of $\mathrm{XR}_{3}$ for complete removal are -7.327439 which is also significant. The log-odds of $\mathrm{XR}_{3}$ for complete burning are 8.523872, the coefficient is positive. The coefficient of $\mathrm{XR}_{3}$ for partial burning is 6.99977 showing consistent signs with the economic theory.

Farmers having cattle are more likely to remove most parts of the residue as a feed for animals. It was expected that farmers having a small farm size and having more cattle on field will either remove the residue completely or major part of it be removed because of its need. Having less number of cattle and large size of farm was expected to have completely different outcome and is so proved by the results of our multinomial logit model for rice residue. Results can be seen from Table 4; the multinomial log-odds are 0.8758508 for complete removal, -1.185579 for complete burning, and -1.145018 for partial burning. The results of this variable are also consistent with the economic theory. 
"Distance of field to farmers' home" is yet another important explanatory variable. It was expected if the distance between farmers' homes and fields is more, the collection of residue and bringing that to home will be expensive for the farmers. The chance of burning residue was expected to be more for those who have greater distance between their home and field. The negative and significant coefficient of the variable associated with complete removal and significant positive coefficient of the variable associated with complete and partial burning of residue confirms the economic theory

The view of the positive impact of burning residue on the following crop also affects the crop residue management decision. The log-odds of $\mathrm{XR}_{6}$ for complete removal are not significant but the coefficient has negative sign showing that if the farmers have the above-mentioned belief then they do not favor the removal of complete residue from the field. The multinomial log-odds of $\mathrm{XR}_{6}$ for complete burning and partial burning are 7.413933 and 6.437715 respectively.

Other variables that do affect the rice residue management practices in the study area but are not significant in our model are: the use of combine harvester, reading agricultural publications, and occupation of the farmers.

\subsubsection{Results and discussion of wheat residue management practices}

The results of wheat residue management practices are presented in table 5. Like the previous model, the base category is the partial incorporation of wheat residue. All of the variables have the expected signs and are following the theory. The significant variables of the model are (1) wheat chopper machine, (2) size of farm, (3) distance of field to farmers home, (4) reading agricultural publications, (5) combine harvester, (6) length of straw. Other important factors used in the study are: incorporation of wheat residue decreases yields of next crop, convenience in the use of farm machinery, and farmer's contact with the extension agent. Cattle ownership does not affect the wheat residue practice due to cultivation of berseem and other Rabi fodder which are used as feed for animals.

Partial burning of wheat residue is the dominant practice in the study area followed by complete removal and complete burning. This is because of the farmers' view regarding the negative impact of residue incorporation on the following crop. Farmers are of the view that wheat residue does not mix and destroy in the soil properly like rice residue and sustains itself on the surface of field, thus restricting germination of the seeds of next crop. The complete removal of residue is due to the use of wheat chopper machine for the harvesting of wheat crop instead of combine harvester, which on the one side harvests the crop and on the other side makes hay 
of wheat bhoosa (called thodhi by local people). Finally, the whole residue is burnt by those farmers who have large farm size and for them, clearing and preparing the field for the coming crop is a big problem, which forces them to burn the residue in the open field.

Table 4: Results of Multinomial Logit Model (log odds) of Rice Crop

\begin{tabular}{|c|c|c|c|c|}
\hline Symbol & Variable Name & $\begin{array}{l}\text { Complete Re- } \\
\text { moval }\end{array}$ & $\begin{array}{l}\text { Complete Burn- } \\
\text { ing }\end{array}$ & Partial burning \\
\hline XW1 & Wheat Chopper Machine & $\begin{array}{l}2.011711^{*} \\
(1.061446)\end{array}$ & $\begin{array}{l}-11.14794 * * \\
(5.414104)\end{array}$ & $\begin{array}{c}-10.21448^{*} \\
(5.37347)\end{array}$ \\
\hline XW2 & $\begin{array}{l}\text { Residue Incorporation de- } \\
\text { creases yields of following } \\
\text { Crop }\end{array}$ & $\begin{array}{l}-2.018975^{*} \\
(1.140392)\end{array}$ & $\begin{array}{c}1.535572 \\
(2.268774)\end{array}$ & $\begin{array}{c}1.233022 \\
(2.204437)\end{array}$ \\
\hline XW3 & Farm Size (in Acre) & $\begin{array}{l}-0.1160225^{*} \\
(0.0655443)\end{array}$ & $\begin{array}{l}0.5259156^{* *} \\
(0.2503962)\end{array}$ & $\begin{array}{l}0.4156094^{*} \\
(0.2494183)\end{array}$ \\
\hline XW4 & $\begin{array}{c}\text { Distance of Field to Farm- } \\
\text { er's Home }\end{array}$ & $\begin{array}{l}-1.315098^{* *} \\
(0.5620773)\end{array}$ & $\begin{array}{l}3.327344^{*} \\
(1.71797)\end{array}$ & $\begin{array}{l}2.834552^{*} \\
(1.695298)\end{array}$ \\
\hline XW5 & $\begin{array}{c}\text { Convenient in the use of } \\
\text { Farm Machinery }\end{array}$ & $\begin{array}{l}0.870054 \\
(1.141582)\end{array}$ & $\begin{array}{l}5.411217^{*} \\
(3.151516)\end{array}$ & $\begin{array}{l}5.921903^{*} \\
(3.116464)\end{array}$ \\
\hline XW6 & $\begin{array}{c}\text { Farmer's Contact with the } \\
\text { Agricultural Extension } \\
\text { Agent }\end{array}$ & $\begin{array}{c}0.3883253 \\
(0.7620675)\end{array}$ & $\begin{array}{l}-1.407129 \\
(1.545228)\end{array}$ & $\begin{array}{c}-0.8891052 \\
(1.46134)\end{array}$ \\
\hline XW7 & $\begin{array}{c}\text { Reading Agricultural } \\
\text { Publications }\end{array}$ & $\begin{array}{l}2.002257^{* *} \\
(1.008339)\end{array}$ & $\begin{array}{l}-6.033631^{* *} \\
(3.053819)\end{array}$ & $\begin{array}{l}-6.332555^{* *} \\
(3.007803)\end{array}$ \\
\hline XW8 & Combine Harvester & $\begin{array}{l}-2.549602^{* * *} \\
(0.9844717)\end{array}$ & $\begin{array}{l}0.6486633 \\
(1.931319)\end{array}$ & $\begin{array}{c}1.133814 \\
(1.808791)\end{array}$ \\
\hline XW9 & Straw Length (in Feet) & $\begin{array}{l}-2.105828 \\
(2.528113)\end{array}$ & $\begin{array}{l}9.083087^{* *} \\
(4.484153)\end{array}$ & $\begin{array}{c}8.631582 * * \\
4.381124\end{array}$ \\
\hline Cons & Constant & $\begin{array}{c}5.80774 \\
(7.899488)\end{array}$ & $\begin{array}{l}-36.60719^{* *} \\
(16.63599)\end{array}$ & $\begin{array}{l}-31.39119^{*} \\
(16.26777)\end{array}$ \\
\hline
\end{tabular}

Standard error in the parentheses, ${ }^{* * *} \mathrm{p}<0.01,{ }^{* *} \mathrm{p}<0.05,{ }^{*} \mathrm{p}<0.10$

Note: - Here in this multinomial Logit model, for our simplicity, I have used the "upper part removal and lower part Incorporation" practice as the base outcome of the multi-valued categorical dependent variable.

\subsection{Crops' residues as a source of bio-energy}

In addition of our present study, we have also tried to assess the futrue course of action regarding crop residue management in Pakistan. We found that crops' residues have tremendous potential for generating power. Husk and straw of rice crop 
can be utilized beneficially for bio-energy production. Empirical estimates confirms that $290 \mathrm{~kg}$ of rice straw can produce $100 \mathrm{kWh}$ of electricity and 1 ton of rice husk has the potential to produce about 410-570 kWh of electricity (Zafar, 2014). Such statistics can roughly be used for our study as we have surveyed plots of 5079.5 acres in the study area. The complete removal of residue accounted only for 26.50 percent of the study area while the partial incorporation of crops' residue was found only on 16.50 percent. Of the remaining 57 percent of the residue in the study area, farmers either burn the residue completely $(26.50 \%)$ or burn only the lower parts of residue (30.5\%). It was found that 36 mund (Mund $=40 \mathrm{~kg}$ in Punjab) residues are produced per acre of rice crop and wheat residue is produced as $33 \mathrm{mund} / \mathrm{per}$ acre. Cultivated area under rice crop was 4553 acres while area allocated for wheat crop was found to be 4313 acres in the surveyed fields of district Gujranwala. Roughly, we can estimate that if rice residue produced per acre is 36 mund, then on 4553 acres area 163908 mund i.e. 6556.32 tons of rice residues are produced in the study area. This might mean that about $2300 \mathrm{kWh}$ electricity can be produced if the rice residue is utilized beneficially as if $290 \mathrm{~kg}$ rice straw $=100 \mathrm{kWh}$ electricity then 6556.32 tons of rice straw $=2300 \mathrm{kWh}$ of electricity. However, this necessitates cost-benefit analysis of the proposed intervention, which should be deliberated in the forthcoming studies.

\section{Conclusion and Recommendations}

Based on the aforementioned results we conclude that the size of the farm is the most important variable in the residue management practices of rice and wheat crops. The large farm size increases the time and financial cost of removal of crops' residue. Besides, the decision of whether to burn or not to burn the residue is also affected by time interval between successive crops, length of straw, distance of field to farmers' home, number of cattle on field, and the price of residue in the market. In this regard, the contact of the farmers with the extension agent and reading agricultural magazine are seen key to removal of rice and wheat residue from the field. We suggest that awareness of the farmers about the negative impacts of crops' residue burning on the environment, physical properties of soil and successive crop yield are very important. More important potential solutions include the use of wheat and rice residue for power generation by converting crops' residue into biogas. At present, the Government of Punjab is also contemplating a feasibility study on the power generation from rice and wheat residue. For this purpose, the farmers were asked about their willingness to accept (WTA) for the collection of the residue and abandoning the burning of residue. The compensation demanded by the farmers on average was Rs. 4000/acre. The use of wheat chopper machine and Kubota harvester machine is also highly recommended because these machines significantly and positively affect the management practices of residues in the studied region as farmers equipped with 
such machines do not burn the crops' residue. We assert that installation of power plant for converting crops' residue into biogas and providing new machines for removal of crops' residue on micro-credit and on subsidized rates can significantly affect the crop residue management practices in Pakistan. These policy interventions have become necessary as air pollution is increasing day by day as a consequence of crops' residue burning. However, such policy interventions will take time to bear fruit as the government also needs to educate the stakeholders about the usefulness of such policy interventions. Stakeholders, such as, farmers need to be made aware of the benefits of embedding sustainability in their farm operations. Education of stakeholders with associated governmental support can have far reaching positive effects on crop residue management practices and on the reduction of air pollution in Pakistan.

The study has some limitations also. Firstly, it is only limited to district Gujranwala of Punjab, Pakistan. Secondly, this study is based on merely 200 individuals farmers interviews. Our study has not used any proxy for peer effect (i.e. whether a farmer's decision to adopt a particular form of residue practice is influenced by other farmers' decision) which we think should be looked into as a future research agenda.Nevertheless, the novelty of the study is incorporation of many important factors contributing to crop residue management practices, and suggesting the idea of electricity generation by crops' residue utilization.

\section{References}

Ahmed, T. \& Ahmad, B. (2013). Why do farmers burn rice residue? Examining farmers' choices in Punjab, Pakistan. Working paper no 76-13, South Asian Network for 24 Development and Environmental Economics, GPO 8975, E.P.C 1056, Kathmandu, Nepal.

Auffhammer, M., Ramanathan, V., \& Vincent, J. R. (2012). Climate change, the monsoon, and rice yield in India. Climatic Change, 111, 411-424.

Bahrani, M. J., Raufat, M. H., \& Ghadiri, H. (2007). Influence of wheat residue management on irrigated corn grain production in a reduced tillage system. Soil and Tillage Research, 94(2), 305-309.

Bhuvaneshwari, S., Hettiarachchi, H., \& Meegoda, J. N. (2019). Crop Residue Burning in India: Policy Challenges and Potential Solutions. International Journal of Environmental Research and Public Health, 16(5), 832 .

Cavalett, O., Slettmo, S. N., \& Cherubini, F. (2018). Energy and environmental aspects of using eucalyptus from Brazil for energy and transportation services in Europe. Sustainability, 10(11), https:// doi.org/10.3390/su10114068.

Derpsch, R., \& Friedrich, T. (2010). Global overview of conservation agriculture adoption. Società Italiana de Agronomia XL Convegno Nazionale, Università degli Studi Teramo, 7(9), 13-17. 
Gupta, P. K., Sahai, S., Singh, N., Dixit, C. K., Singh, D. P., Sharma, C., Tiwari, M.K., Gupta, R. K., $\&$ Garg, S.C. (2004). Residue burning in rice-wheat cropping system: Causes and implications. Current Science, 87(2), 1713-1717.

GoP, (2003). Agricultural statistics of Pakistan; the ministry of food, agriculture and livestock. Economic wing, Islamabad, Pakistan, Year book 2003-04.

Hoffman, S. D., \& Duncan, G. J. (1988). Multinomial and conditional logit discrete-choice models in demography. Demography, 25(3), 415-427.

Hussain, I., Shah, H., Azeem, K. H., Akhtar, W., K., Majid, A., \& Mujahid, Y. M. (2012). Productivity in rice-wheat crop rotation of Punjab: An application of typical farm methodology. Pakistan Journal of Agriculture, 1 (25), 1-5.

Jain, N., Bhatia, A., \& Pathak, H. (2014). Emission of air pollutants from crop residue burning in India. Aerosol and Air Quality Research, 14(1), 422-430.

Lee, L. K., \& Stewart, W. H. (1983). Land ownership and the adoption of minimum tillage. American Journal of Agricultural Economics, 65(2), 256-264.

Mobeen, K. (2009). Wheat crop residues for soil fertility. Economics and Business Reviews, the daily Dawn, Published Jun 08, 2009. http://www.dawn.com/news/469835/wheat-crop-residues-for-soil-fertility.

Pathak, H., Bhatia, A., Jain, N., \& Aggarwal, P. K. (2010). Greenhouse gas emission and mitigation in Indian Agriculture-A Review. Indian Nitrogen Group (ING) Society for Conservation of Nature, Bulletin No. 19 , i-iv \& 1-5.

Preez, C. C., Steyn, J. T., \& Kotze, E. (2001). Long-term effects of wheat residue management on some fertility indicators of a semi-arid Plinthosol. Soil \& Tillage Research, 63, 25-33.

Qaim, M., \& Zilberman, D. (2003). Yield effects of genetically modified crops in developing countries. Science, 299(5608), 900-902.

Singh, B., \& Kumar, D. (2018). Crop residue management through options. International Journal of Agriculture, Environment and Biotechnology, 11(3), 427-432.

Useche, P., Barham, B. L., \& Foltz, J. D. (2009). Integrating technology traits and producer heterogeneity: A mixed-multinomial model of genetically modified corn adoption. American Journal of Agricultural Economics, 91(2), 444-461.

Zafar, S. (2014). Rice straw as bio-energy resource. Available at: http://www.bioenergyconsult.com/tag/ rice-straw/ 
